Article

\title{
Euroregion as an Entity Stimulating the Sustainable Development of the Cross-Border Market for Cultural Services in a City Divided by a Border
}

\author{
Łukasz Wróblewski 1,*(D) and Andrzej Kasperek ${ }^{2}$ (D) \\ 1 Department of Management and Production Engineering, WSB University, \\ 41-300 Dabrowa Górnicza, Poland \\ 2 Faculty of Ethnology and Education, University of Silesia in Katowice, 43-400 Cieszyn, Poland; \\ andrzej_kasperek@wp.pl \\ * Correspondence: lwroblewski@wsb.edu.pl; Tel.: +48-692-344-057
}

Received: 1 March 2019; Accepted: 10 April 2019; Published: 13 April 2019

check for updates

\begin{abstract}
This article discusses the issue of the sustainable development of the Polish-Czech cross-border market for cultural services in a city divided by an international border. The article uses the example of Cieszyn and Český Těšín, a city divided following the decision of the Council of Ambassadors in 1920. The research carried out so far indicates the main constraints in the harmonious functioning of the cross-border market for cultural services in this city, such as: The different cultural policies implemented on both sides of the city, the language barriers, as well as some legal and administrative differences. Therefore, the authors undertook research aimed at recognising the role of Euroregional structures in stimulating the sustainable development of this region. On the basis of an analysis of the Cieszyn Silesia Euroregion's documentation, and the results of qualitative and quantitative research, this article describes the role of the Euroregion in building a cross-border market for cultural services. The presented results shows that the level of familiarity with cultural events organised in Cieszyn and Český Těšín within the framework of Interreg cross-border projects, is much higher than the familiarity with cultural events that are organised without financial support received through the Euroregion. Recommendations were also prepared that could constitute the principles of a common cultural policy, not only for Cieszyn and Český Těšín, but also for other European cities in the Schengen Area, which, like Cieszyn and Český Těšín, have been divided by an international border.
\end{abstract}

Keywords: Euroregion; city divided by a border; cross-border markets; culture; sustainable development

\section{Introduction}

The issue of European cities divided by a border is an important subject of research, which is conducted within various areas of scientific disciplines. Very often this topic is undertaken by political scientists, whose analysis focuses on the issue of the changing functions of state borders, or the functioning of local self-government administration in the era of European integration, etc. [1-3]. Sociologists, in turn, focus their research on the transformation of the social structures of those cities divided by an international border. In particular, they are interested in the exchange processes in the sphere of values, habits and customs taking place as a result of the "fading away" of the border, which for a long time had separated neighbouring communities from each other [4-6]. Representatives of sciences such as social psychology or cultural anthropology focus their research upon the identity of the collective communities living in such divided cities.

Among other things, they try to find the answer to the question of whether or not a new kind of collective identity, or a new quality of social capital, is shaped in cities divided by a border. They are also 
interested in the issues of creating national narratives after the division, problems of collective memory, antagonisms and reconciliation [7-9]. Finally, cities divided by a border constitute an important object of interest for representatives of the economic sciences, including management sciences. An analysis of articles published in the Web of Science, Scopus or Research Gate databases shows that the attention of economists focuses mainly on the functioning of border markets (the formation of local cross-border markets), in particular cross-border tourism regions, or cross-border labour markets [10-12]. However, it turns out that the issue of the conditions of the functioning and development of possibilities in the cross-border market for cultural services is not raised very often. There is a clear knowledge gap in this area. Among other things, the purpose of this article is to contribute to partially filling this gap.

\section{Literature Review}

\subsection{The Concept of a City Divided by a Border}

Attempting to describe the role of the Euroregion in stimulating the sustainable development of a cross-border market for cultural services in a city divided by a border, we encounter the problem of the existence of the many different terms used to describe such cities. In the category of cities connected with each other along an international border, there are such terms as: "divided cities", "duplicated cities", "connected cities", "twin cities", "sister cities", "paired cities", "trans-border cities", "companion cities" or even "neighbour cities" [7,9,13-15]. These are quite roomy categories. They include cities that were created along the border at a certain distance from each other, cities which are exactly next to each other, as well as those, in which the authors are interested-cities which have been split, but previously constituted a single urban organism (Figure 1).

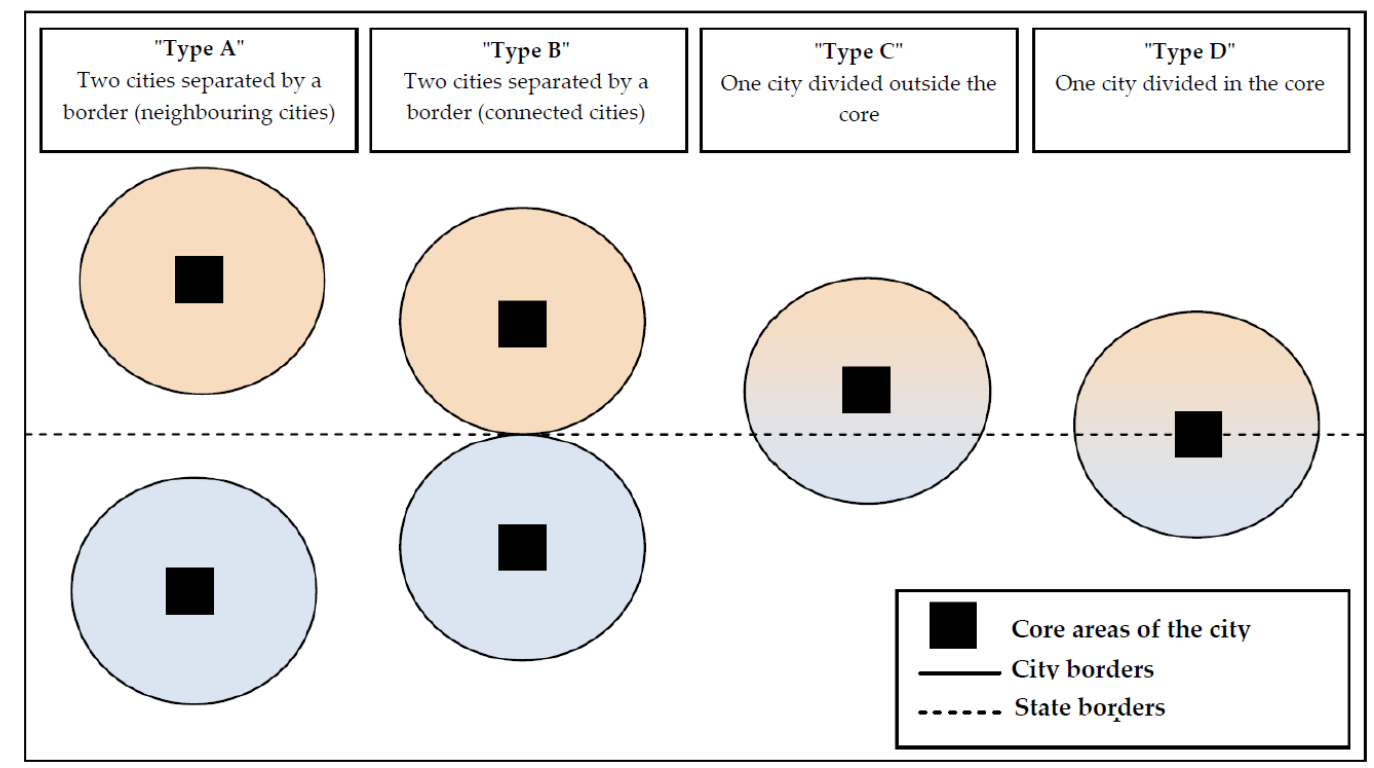

Figure 1. Types of cities divided by a border. Source. Own study based on $[9,13,15]$.

The first category of cities separated by a border ("Type A" - neighbouring cities) generally refers to two separate cities. They are cities that are not connected with each other, but are not too far away from each other-"neighbour cities" or "companion cities", e.g., San Diego and Tijuana [7] (pp. 15-17). A separate category is made up of connected cities ("Type B") also known as "gate-cities"-located on the exact border, and performing various functions related to border traffic [16] (p. 269). It is worth noting that some of these cities are "duplicated cities", which, as a result of integration, can account for "connected cities". The occurrence of this type of city is characteristic of Western and Northern Europe and other places characterised by the presence of stable borders [17-19]. 
In the case of the next category of divided cities-one city split by a border ("Type $C$ " and "Type D"), two features play a special role: The heritage of unity and the immediate spatial proximity. The first is associated with historical memory dating back to the period before the division, but also with material remains from the period of unity-the so-called 'core' areas of the city (architecture, urban infrastructure, etc.). The second is "manifested by the spatial cohesion of urban organisms" [3,19]. According to Schulz et al. it is this type- "divided cities" - that can be considered as true "twin cities" [3] (pp. 4-5), which, as a result of various historical experiences, usually bear names similar to each other, and are recognisable in both languages, as is the case in the cities of Cieszyn and Český Těšín. On the one hand, both parts of the city can remain in almost complete separation, but on the other hand they can constitute a relatively uniform urban organism in terms of infrastructure, social aspects and economy. It should also be noted that these cities may have been "broken up" in various ways. In some cases, the core areas of the city (the historical or cultural city centre) remain entirely on one side of the border (as in the case of Cieszyn and Český Těšín), while in others, the core of the city is divided between two countries (a special case of such a city is Rome and the Vatican). Considering the cities which have been split in the European context ("Type C" and "Type D"), it can be pointed out that they are characteristic of Central and Eastern Europe as well as South-Eastern Europe, which is a part of Europe characterised by the greatest fluidity of borders, and the change of the territorial range of countries. The research results presented in the paper refer to these types of cities. According to the findings of the authors, the divided cities in the European continent ("Type C" and "Type D") include 26 city pairs, including eighteen on the internal borders, and eight on the external borders of the European Union (Table 1).

Table 1. Cities divided by a border in Europe—“Type C" and “Type D" (as of 1 April 2019).

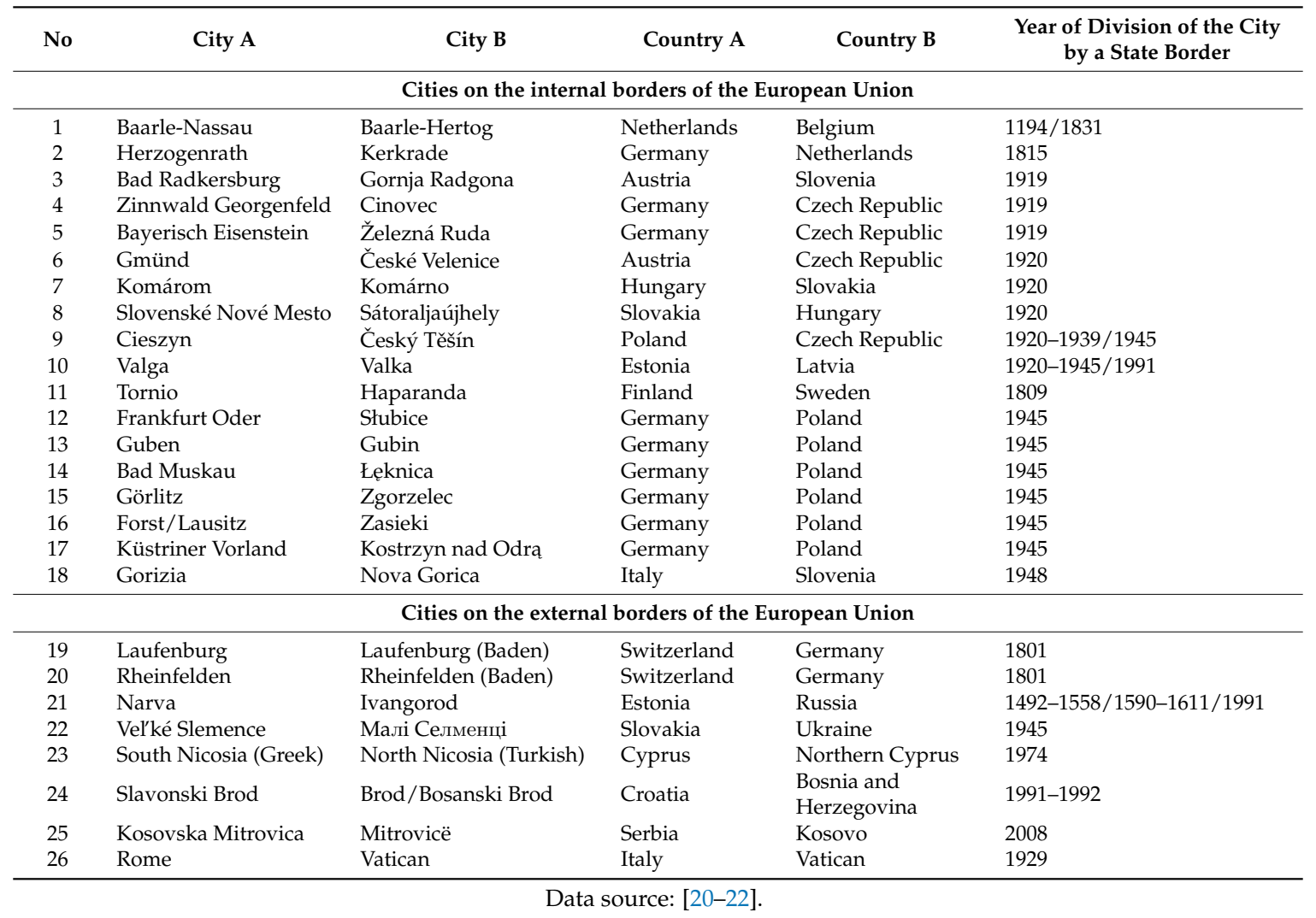

For the most part, the broken-up cities were divided into two sections, nevertheless, divisions into a few or even several parts have occurred in the history of Europe. This category of cities includes Baarle-Nassau and Baarle-Hertog, established in 1831 on the Dutch-Belgian border, which created a unique spatial structure. There is the rare case of 30 enclaves and exclaves on the European continent, 
resembling a jigsaw puzzle, of which the individual parts belong to two countries [23,24]. An example of a city that in its history was a city divided into more than two parts is Berlin, which after the end of World War II was divided into four occupation zones (French, British, American and Soviet).

\subsection{Cross-Border Market for Cultural Services in a City Divided by a Border}

When defining the cross-border market for cultural services in a city divided by a border, both economic and geographical market definitions have been used [25], according to which the cross-border market for cultural services will mean all of the exchange relations between service providers that meet cultural needs, and the consumers purchasing these services in the area of cities divided by an international border [24]. In other words, it will be a collection of buyers ("hidden", potential and active customers) and sellers (cultural institutions), who carry out the transactions related to cultural services in cities divided by a border. A geographical understanding of the cross-border market for cultural services indicates the territory, which is located on both sides of a border, as a separate area with similar purchasing and selling conditions. The classic (economic, systemic) understanding of the market reduces the definition of the cross-border market for culture services to the general exchange relations between sellers, offering services that meet cultural needs and buyers-representing a demand for these services. It includes both the subjective (the one who participates in the trading process) and the objective aspect (the object of trade) [26].

The cross-border market for cultural services in a divided city should therefore be treated as a system whose elements form a specific structure (Figure 2). In this system, we can distinguish [26-28]:

- Market entities that are sellers (public and private cultural institutions) and buyers ("hidden", potential and active customers);

- Market objects, i.e., cultural services and aesthetic needs, the motives of using the services of cultural institutions, revealed in the market);

- Relations between market entities and objects.

The functioning of the cross-border market for cultural services is influenced, both by activities undertaken by domestic cultural institutions, and those in the neighbouring country, as well as buyers from both sides of the border who may act as "hidden" customers, reporting an undisclosed (anonymous) demand for cultural services as a potential customer, showing interest in the cultural institution's offer of services, as well as an active customer-a participant using the services of cultural institutions. In turn, cultural institutions recognise the needs of buyers, through appropriate educational activities. They also try to stimulate, present and submit an offer, and then provide the services. The existing connections in the cross-border market for cultural services between cultural institutions and customers are presented in Figure 3.

The authors assumed that the sustainable development of the cross-border market for cultural services in a city divided by a border will be manifested in:

- An increase in supply-in particular, an increase in the number of cultural institution services addressed to consumers from both sides of a city divided by a border;

- More frequent use of cultural services by residents of a city divided by a border, as well;

- The growth of cultural services contributing to the protection and development of specific values of local, regional and ethnic cultures, to strengthening "small homelands", in order to shape a diverse "homeland culture", and not just a unified "pan-European" culture. 


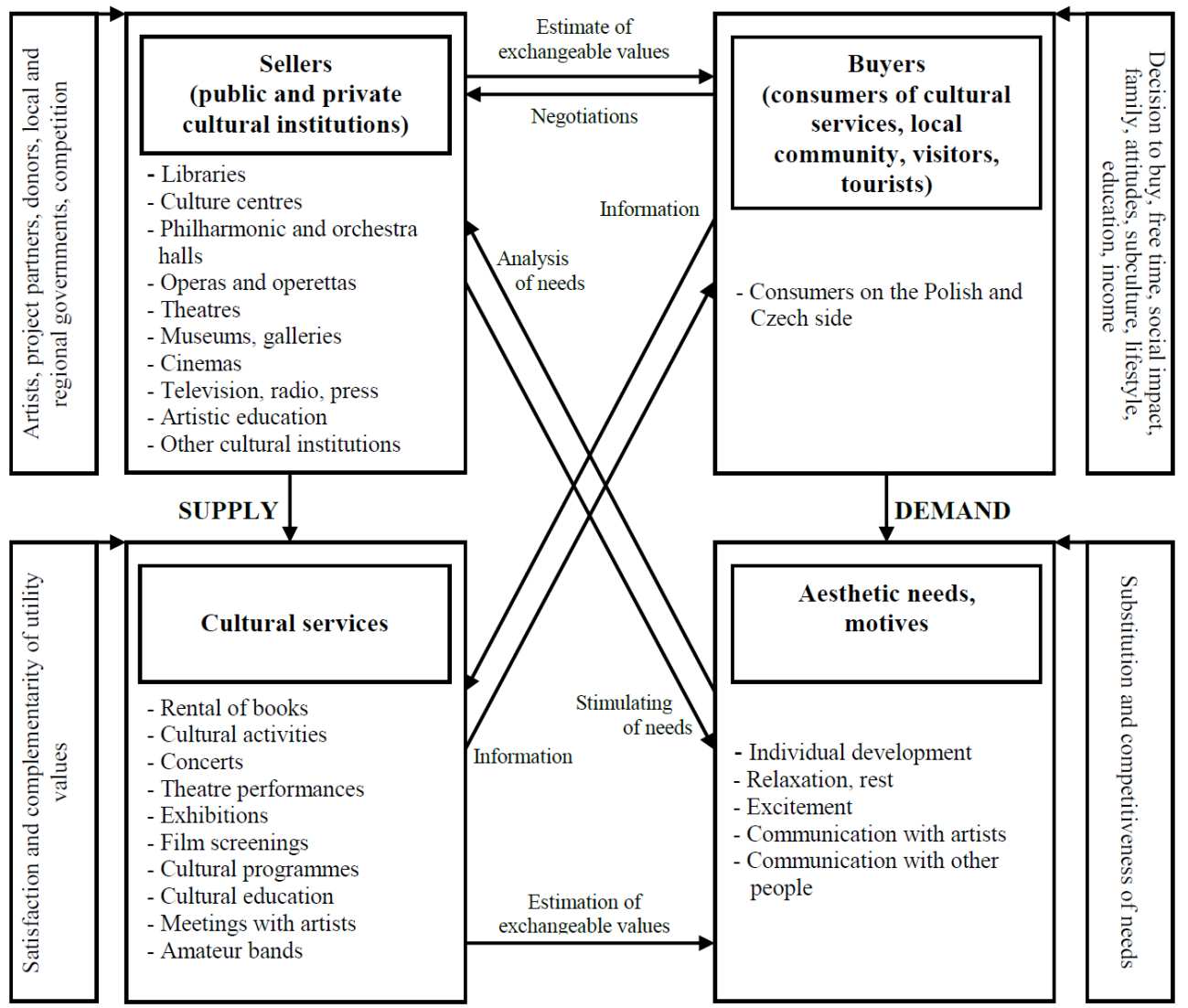

Figure 2. The structure of the cross-border market for cultural services in a city divided by a border. Source. Own study based on [26-28].

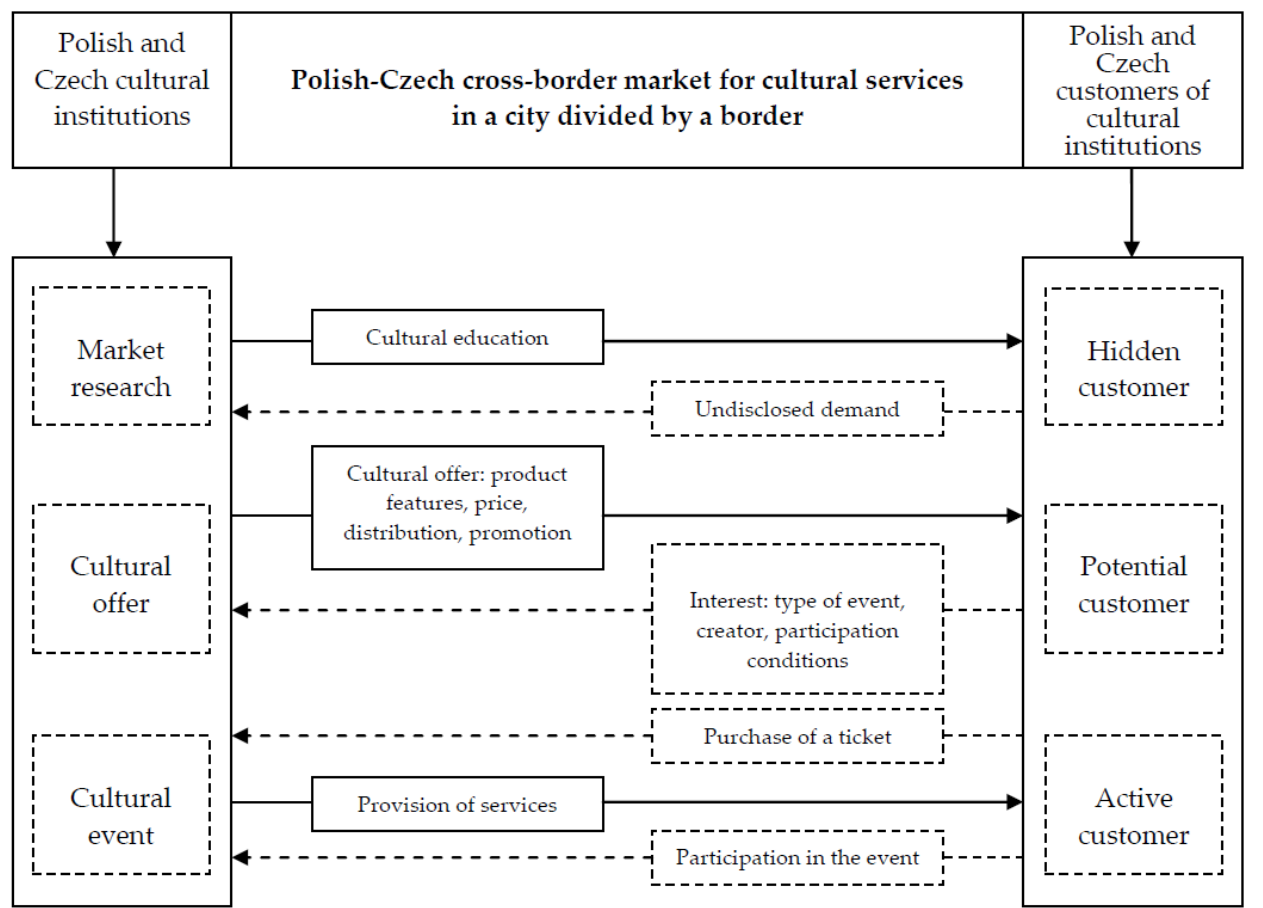

Figure 3. The relationships between cultural institutions and customers in the cross-border market for cultural services. Source. Own study based on [29]. 


\subsection{Euroregion as an Entity of the Cross-Border Market for Culture Services}

Cross-border cooperation in Europe organised in the form of Euroregions began on the Dutch-German border in 1958. The first Euroregion, called Euroregio, was created there, which was then adopted as the name for this type of cooperation [30,31]. The functioning of Euroregions is primarily based on contracts concluded between regional and local authorities, but the active participation of entities from other sectors of the economy is also common. Euroregional cooperation aims to undertake and harmonise various activities in the field of culture, as well as science, education or the economy [32]. It is very important that these activities should be beneficial for both sides, and should also deepen mutual relationships between institutions, economic entities and the inhabitants of local communities [33-35]. The advantage of Euroregions is certainly their greater flexibility in the scope of the activities undertaken. A wide range of statutory activities enables them to support the implementation of cross-border cultural initiatives, among other things. It can be assumed that these entities have a much "more comfortable" position than local governments, which must implement a certain set of tasks. The main goals of Euroregions include [36-39]:

- Shaping a new quality of borders, which should become meeting places and not divisive ones, smoothing the "seams" of European spatial planning policy,

- Overcoming deficits in the location and use of opportunities by improving transport infrastructures and supporting the attractiveness of the regions and their common economic development,

- Strengthening cross-border environmental and nature protection,

- Partnerships and assistance (subsidiarity), understood as the basic principles of the functioning of border regions and the subregional units that form them, as well as state and European institutions,

- And finally, support for cross-border cultural cooperation, which may directly translate into the issue which interests the authors-the sustainable development of the cross-border market for cultural services.

The establishment of the Cieszyn Silesia Euroregion in 1998, which on the Polish side is represented by the Olza Association for Regional Cooperation and Development (SRiWR) (the equivalent on the Czech side is Regionální sdružení územní spolupráce Těšínského Slezska) can be treated as an attempt to reconstruct the network of mutual trust, by developing mechanisms for cooperation between the Polish and Czech entities in the cross-border market for cultural services. The possibility of acquiring external funds from projects, which the Cieszyn Silesia Euroregion started to manage in 1999, became a pretext for establishing Polish-Czech cooperation in the field of culture. This cooperation has sometimes been reluctant, and filled with distance (especially in the first years of the Euroregion's existence). Overcoming mutual reluctance by cooperation in the area of culture is a prerequisite for the development of the entire region, including the sustainable development of the cross-border market for cultural services [40]. The reason is that it is difficult to imagine the harmonious functioning of this market, when its most important players enter into constant disputes with each other. It should be noted that from the very beginning, cultural projects have been an important part of the Cieszyn Silesia Euroregion's activities, and have contributed to the development of the Polish-Czech cross-border market for cultural services [41].

The functioning of this market is, therefore, the result of the implementation of the principles of local, national and EU cultural policies by various entities. In the case of the Cieszyn Silesia Euroregion and other Euroregions, the local, national and EU levels intersect. The Euroregion's activity in acquiring and distributing EU funds and the state budget, translates into the implementation of local projects with a cultural character. The projects implemented may in turn contribute to the improvement of the quality of the life of residents of a city divided by a border. The Euroregion thus becomes one of the main players in the cross-border market for cultural services. The Euroregion's activities that stimulate the sustainable development of this market in a city divided by a border should therefore rely on initiating and supporting cross-border cultural projects focused on recognising diversity as something 
valuable in social life, as well as measures not only promoting tolerance towards cultural diversity in the local community, but also the acceptance of these differences, and recognising them as valuable.

\section{Materials and Methods}

\subsection{Cieszyn-Český Těšin as the Research Area}

The focus of research in this article is a city, which since the end of World War I, has been divided into Cieszyn on the Polish side of the border (about 36,000 inhabitants) and Český Těšín (Czech Republic, with approximately 25,000 inhabitants). It is a system of cities that, in 2007, entered the so-called Schengen Area, i.e., a visa-free movement without border checks (Figure 4).

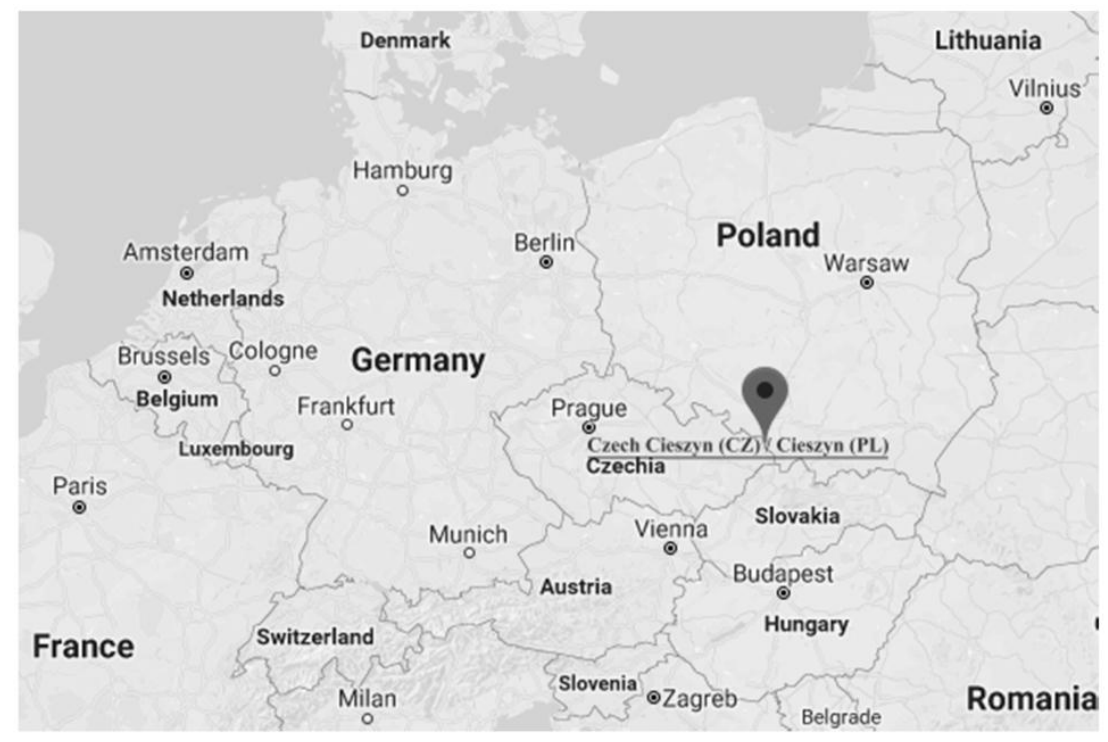

Figure 4. Location of the border cities Český Těšín (CZ)/Cieszyn (PL).

Despite the opening of borders and the development of the cross-border market for cultural services, the functioning of cultural institutions both on the Polish and Czech side of the city are still intertwined with the city's/cities' past history. That is, not only the most recent history, but that going back hundreds of years.

The cultural offerings of both cities are being developed by numerous cultural entities whose offers are not limited only to the consumers on one side of the border. Despite the relatively small size, the city as a whole has two theatres. The Polish side has the Adam Mickiewicz Theatre, and the Czech side has a theatre with a double, Polish and Czech, stage. What is particularly interesting is that the Polish stage located in Těšínském Divadle is financed by the Czech marshal's office, without subsidies from Polish sources. Two large cultural centres operate in the city as a whole: The Dom Narodowy Cieszyn Cultural Centre House, and the Kulturní a společenské středisko Střelnice.

Important cultural spots include the Municipal Library in Cieszyn, the Municipal Library in Český Těšín (Městská knihovna Český Těšín), the Avion Reading Room and Literary Café (Čítárna a kavárna Avion), the internationally known Cieszyn Castle, involved in the area of design, the Museum of Cieszyn Silesia, as well as the Cieszyn Library, containing many unique publications spanning over the last five hundred years. Sustainable development for both cities also includes the activities of associations. The most prominent ones include the already mentioned Olza Association for Regional Development and Cooperation, the Polish Cultural and Educational Association, the Polish Congress in the Czech Republic, the Kultura na Granicy (Culture on the Border) Association, the Člověk na hranici (Man on the Border) Association, the Polish-Czech-Slovak Solidarity and the Education Talent Culture Association in Český Těšín. We should also not forget about the more or less significant initiatives and places held in private hands. Such places also enrich the supply side of the cross-border 
market for cultural services. These include the Kornel i Przyjaciele Literary Café, the Laja Tea House, the Dziupla Club, the Blady Świt (Bledý úsvit) Bar, or events like the series of charity concerts called Aktywuj Dobro. The above group is enriched by activities in the social sphere, undertaken by third sector organisations, for example, the Być Razem Association for Mutual Assistance. The fact that, in terms of quantity, non-governmental organisations have their headquarters mainly on the Polish side, is of great significance for the social and cultural capital of the city as a whole. In Český Těšín, this type of social involvement has not been created [26].

\subsection{The Main Purposes, Methods and Techniques of the Research}

The main purposes of the research carried out in Cieszyn and Český Těšín was:

- To characterise the Polish-Czech cross-border market for the cultural services of a city divided by a border;

- To define the role of the Cieszyn Silesia Euroregion in shaping the cross-border market for cultural services in Cieszyn and Český Těšín;

- To develop the principles of a common cultural policy of a city divided by a border, taking into account the sustainable development of the cross-border market for cultural services.

In pursuing such a goal, a general hypothesis was adopted containing the assumption that the activity of the Cieszyn Silesia Euroregion stimulates the sustainable development of the cross-border market for cultural services in Cieszyn and Český Těšín. This development is visible on both the supply and demand side of the market, and manifests itself in:

- The growing number of Polish-Czech cultural projects whose beneficiaries are residents of both the Polish and Czech sides of the city (growth of the supply side),

- The greater frequency of the residents of Cieszyn and Český Těšín taking advantage of the cultural offerings that are available on both sides of the border (growth of the demand side).

The research was carried out using the following research methods and techniques:

- Desk research analysis covering documents and materials of the Cieszyn Silesia Euroregion, and reports from self-government cultural institutions for 2014-2016;

- Quantitative research-surveys, in which 799 respondents took part (about $1.31 \%$ of all city residents on both sides of the border), i.e., 490 inhabitants of Cieszyn (61.25\%) and 309 inhabitants of Český Těšín (38.75\%) who, in 2017, at least once, took advantage of the offerings of cultural entities based in one of the mentioned cities. The research was carried out in the form of street surveys handed out, and online surveys. The survey questionnaire was developed in both Polish and Czech. Electronic questionnaires were made available to the residents of Cieszyn and Český Těšín at the following Internet addresses: https:/ /goo.gl/forms/Gu7E23zM9uFxgVfD2 (questionnaire in Polish), https://goo.gl/forms/eS2GwmnaMQ40k3NU2 (questionnaire in Czech). Surveys were conducted from October 2017 to January 2018. The socio-demographic description of surveyed inhabitants of the Polish and Czech side of the city is included in Appendix A.

- Qualitative research:

- Individual in-depth interviews with representatives of the supply side of the Cieszyn (20 interviews) and Český Těšín (20 interviews) market for cultural services. The list of people interviewed (including the directors of all local cultural institutions, heads of cultural departments, cultural organisers, employees of cultural institutions) is included in Appendix B. Interviews using the questionnaire were conducted from February to June 2018. The interview questionnaire (in Polish and Czech) contained a total of 17 questions, of which 7 were short questions based on associations and "fill in the blank" questions, while the next 10 questions-were in-depth open questions; 
- Individual in-depth interviews with the secretary of the Polish and Czech side of the Cieszyn Silesia Euroregion. An interview with the secretary of the Polish side of the Euroregion was carried out on 12 February 2019, with the secretary of the Czech side conducted on 14 February 2019;

- $\quad$ A consultation meeting of experts with the use of brainstorming techniques with key stakeholders in the cross-border market for cultural services in Cieszyn and Český Těšín, i.e.: Mayors of Cieszyn and Český Těšín, representatives of the Cieszyn Silesia Euroregion, local governments, representatives of cultural institutions, third sector cultural organisations, the heads of culture and promotion departments of both cities). The meeting, which took place in the Municipal Office in Český Těšín on 7 November 2018, was attended by a total of 16 experts ( 9 from the Czech side and 7 from the Polish side).

The research which was carried out was part of two Polish-Czech cross-border projects co-financed by the European Regional Development Fund-Interreg V-A Programme Czech Republic-Poland under the Micro-Projects Fund of the Cieszyn Silesia Euroregion-Těšínské Slezsko and the state budget:

- The "Programme for Cieszyn and Český Těšín Culture" project implemented in 2017-2018;

- The “Český Těšín/Cieszyn InEurope" project implemented in 2018-2019.

\section{Results}

\subsection{Project Activities of the Cieszyn Silesia Euroregion in 1999-2018}

The Cieszyn Silesia Euroregion managed four European programmes in 1999-2018, including:

- In 1999-2003, projects of the Joint Small Projects Fund (WFMP) as part of the Phare CBC Cross-Border Cooperation Programme;

- In 2004-2006, the Community Initiative Programme Interreg IIIA Czech Republic-Republic of Poland;

- In 2007-2013, the Cross-Border Cooperation Operational Programme Czech Republic-Republic of Poland;

- In 2014-2020, the Interreg V-A Programme Czech Republic-Poland.

In total, until 31 August 2018, 594 projects were approved under the aforementioned programmes, of which $302(50.84 \%)$ are projects in the area of culture. The largest number of projects in the area of cultural exchange has been implemented as part of the Phare CBC Cross-Border Cooperation Programme. In the 1999 edition, out of 34 projects accepted for implementation, 19 concerned cultural exchange (57.58\%); in 2000-out of 22 approved projects as many as $16(72.73 \%)$ concerned cultural exchange; in 2001-the percentage of projects in the area of culture was even higher, amounting to $86.67 \%$ (out of 15 approved projects, as many as 13 concerned cultural exchange). In the fourth edition (2002) of the Joint Small Projects Fund managed by the Cieszyn Silesia Euroregion, a total of 13 projects were approved, with 9 related to the cultural sphere $(69.23 \%)$, and in the 2003 edition there were 11 approved projects related to cultural exchange (63.64\%). Thus, in total, in five WFMP editions managed by the Cieszyn Silesia Euroregion, 95 projects were approved, of which as many as $64(67.37 \%)$ concerned cultural exchange.

In 2004-2006, the Cieszyn Silesia Euroregion managed the Community Initiative Programme Interreg IIIA Czech Republic-Republic of Poland. Culture was one of this European programme's areas of interest. During this period, in five calls, 62 projects were approved (submitted by 48 entities), including 35 which were related to cultural activity (56.45\%). The Community Initiative Programme Interreg IIIA Czech Republic-Republic of Poland was implemented in the new, post-accession reality (the Republic of Poland and the Czech Republic became full members of the European Union in May 2014). 
One of the programmes-Cross-Border Cooperation Operational Programme Czech Republic-Republic of Poland (POWT RCz-RP) — covered the period in which Poland and the Czech Republic joined the Schengen Area (2007-2013). As many as 269 micro-projects were approved during that period, of which 140 were managed by the Polish side of the Euroregion (including 68 in the area of culture), and 129 by the Czech side (including 54 in the area of culture).

Since 2016, the Cieszyn Silesia Euroregion has been co-financing projects as part of the Interreg V-A Programme Czech Republic-Republic of Poland, 2014-2020. By 31 August 2018, 149 projects have been approved, of which 70 fall within the cultural sphere (Table 2).

Table 2. The number of Polish-Czech cross-border projects in the area of culture approved for co-financing through the Cieszyn Silesia Euroregion.

\begin{tabular}{|c|c|c|c|c|c|}
\hline Programme Name & $\begin{array}{l}\text { Number } \\
\text { of } \\
\text { Approved } \\
\text { Projects }\end{array}$ & $\begin{array}{l}\text { Total } \\
\text { Co-Financing } \\
\text { in Euros }\end{array}$ & $\begin{array}{l}\text { Number of } \\
\text { Approved } \\
\text { Projects in the } \\
\text { Area of Culture }\end{array}$ & $\begin{array}{l}\text { Co-Financing of } \\
\text { Projects in the } \\
\text { Area of Culture } \\
\text { in Euros }\end{array}$ & $\begin{array}{c}\% \text { of All Projects } \\
\text { Under the Programme } \\
\text { Which Were Cultural } \\
\text { Projects }\end{array}$ \\
\hline $\begin{array}{l}\text { Cross-Border Cooperation } \\
\text { Programme Phare CBC 1999-2003 }\end{array}$ & 95 & $562,291.44$ & 64 & $404,261.95$ & 67.4 \\
\hline $\begin{array}{l}\text { Community Initiative Programme } \\
\text { Interreg IIIA Czech } \\
\text { Republic-Republic of } \\
\text { Poland-2004-2006 }\end{array}$ & 62 & $677,855.86$ & 35 & $398,763.65$ & 56.5 \\
\hline $\begin{array}{l}\text { Cross-Border Cooperation } \\
\text { Operational Programme Czech } \\
\text { Republic-Republic of Poland } \\
\text { (POWT RCz-RP)—2007-2013 }\end{array}$ & 269 & $5,326,707.19$ & 123 & $2,437,493.65$ & 45.7 \\
\hline $\begin{array}{l}\text { Interreg V-A Programme Czech } \\
\text { Republic-Poland 2014-2020 }\end{array}$ & 149 & $3,753,758.08$ & 70 & $1,633,413.47$ & 47.0 \\
\hline Total & 575 & $10,320,612.57$ & 292 & $4,873,932.72$ & 54.2 \\
\hline
\end{tabular}

The undisputed leader among Cieszyn's cultural institutions in raising funds as part of the programmes managed by the Cieszyn Silesia Euroregion is the Museum of Cieszyn Silesia, whose projects were implemented, among others, with the Těšínska Museum, a partner from the Czech side. In the case of cooperation between the two museums (Polish and Czech), institutions located on both sides of the border and implementing national policies, cooperation became particularly important. This cooperation connects both cities, and at the same time, builds a cross-border market for cultural services, as the nature of the projects was clearly indicated in their names, e.g., Exhibition: Cieszyn-Český Těšín, Yesterday and Today, Exhibition: Beskidy-Mountains that Connect, or Two Cities-One Tradition. The subject of the projects carried out by other cultural institutions was also related to this connecting tone. For example, the projects implemented by the "Dom Narodowy" Cieszyn Cultural Centre (Cieszyn Cultural Bridge, United Cieszyn Cultures, Tradition of Both Cieszyns) and the Cieszyn Library (Common roots. The launch of a series of source publications; Common sources. Support for the development of regional education and cross-border historical research, which focused on protecting and promoting the cultural heritage of Cieszyn Silesia).

The cultural institutions of Cieszyn and Český Těšín, such as: Museums, libraries, galleries, theatres and cultural centres, implementing cross-border projects financed through the Cieszyn Silesia Euroregion from the sociological and anthropological perspective, are examples of remembrance institutions responsible for conducting discourse on the memory of the past. It can be assumed, therefore, that these entities are depositaries of remembrance, and through the implementation of Polish-Czech cultural projects, they manage this remembrance in some way. What is very important is that they do it in a sustainable way, because in accordance with the requirements of European programmes, when implementing their projects, they adhere to the guidelines of both Polish and Czech cultural policy conducted both at the national and local level [42]. It is worth mentioning here that the preservation of the nation's cultural heritage has been recognised by the Sejm [Parliament] 
of the Republic of Poland as one of the foundations of Poland's sustainable development strategy. The resolution of the Sejm [Parliament] of the Republic of Poland of 2 March 1999 [43] emphasises the harmonious concern to preserve the natural and cultural heritage of the nation, along with civilisational and economic progress, which is the participation of all social groups. The specificity of the sustainable cultural policy of cities divided by a border will therefore be a concern for the harmonious arrangement of relationships between neighbours, and the preservation of the common cultural heritage-in the case of Cieszyn Silesia, this means traditions, dialect, works of folk or artistic culture. The analysis of the Cieszyn Silesia Euroregion's documentation indicates that cross-border projects based on the promotion and dissemination of common traditions, language or folk culture, most often receive Euroregional support. In addition, the review of reports on the implementation of these projects shows that cross-border activities in the area of culture go beyond the national point of view, and in the case of conflicts between partners (existing in the past), are based on the axiom of mutual reconciliation [44]. Cultural institutions that create the cross-border market for cultural services in Cieszyn and Český Těšín, by implementing joint projects, thus become important links in maintaining the balance between satisfying "current social needs and the needs of future generations". So we could say that the Euroregion, supporting the activities aimed at increasing the knowledge of the achievements of Polish and Czech culture, its spiritual values and valuable moral traditions, stimulates the sustainable development of the cross-border market for cultural services. In particular, it supports activities aimed at common Polish-Czech cultural education and equalising opportunities for access to cultural values. It promotes such shaping and diversification of cultural offerings, so that residents from both the Polish and the Czech part of the Euroregion can benefit from the cultural infrastructure available on both sides of the border.

\subsection{Results of the Quantitative Research-An Examination of the Demand Side of the Market}

One of the main problems related to the functioning of the cross-border market for cultural services analysed by the authors concerned the frequency at which the inhabitants take advantage of the cultural offerings available on both sides of the city divided by a border. The residents of Cieszyn and Český Těšín were asked how often they take advantage of the offerings of cultural institutions and entities located in Cieszyn (on the Polish side of the border). The results, which have been divided into residents of the Polish and Czech side of the city, are presented in Table 3.

The data presented in Table 3 shows that the vast majority of the inhabitants of the Polish side of the city (nearly 70\%), have not taken advantage of the offerings of a significant part of the cultural institutions located in Cieszyn. In the course of further in-depth research, it turned out that in 2017, Polish respondents most often took advantage of the offerings of the Municipal Library in Cieszyn - 20.61\% of respondents, the Cieszyn Castle (17.14\%), and the "Piast" Cinema (17.14\%). The research conducted among the inhabitants of Český Těšín shows that in 2017 over 84\% of the surveyed inhabitants of the Czech side of the city did not take advantage of the offerings of the Polish cultural institutions located in Cieszyn. Czech respondents most often visited such cultural institutions on the Polish side of the city as: The Cieszyn Castle (11.00\%), the "Piast" cinema (4.53\%) and the Municipal Library in Cieszyn (3.24\%), which is most often used by the Polish minority living in the Czech Republic, and affiliated with the Polish Cultural and Educational Association in the Czech Republic (the largest organisation in Europe associated with Poles outside Poland [45]).

Respondents were also asked how often they partook of the cultural offerings of cultural institutions located in Český Těšín. The data presented in Table 3 also shows that Poles living in Cieszyn very rarely visited cultural institutions that are located on the other side of the border. The Těšín Theatre is the cultural institution in Český Těšín, which enjoys the greatest interest among Poles. Nearly 5\% of the surveyed residents of Cieszyn visited this institution in 2017 many times; $4.69 \%$ of the Cieszyn residents surveyed visited the Těśn Theatre three or four times, and $12.45 \%$ of the them did so once or twice. Such a result could have been expected, given the fact that the Těšín Theatre, in addition to the Czech theatre group, features a "Polish Stage"—a group of Polish actors putting on plays in 
Polish. The surveyed inhabitants of Český Těšín declared that they most often took advantage of the offerings of the AVION literary café in Český Těšín, which is located in the immediate vicinity of the "Friendship Bridge" connecting Cieszyn with Český Těšín and the Cieszyn Castle. In 2017 Café AVION was visited multiple times (more than four times) by $22.33 \%$ of the surveyed Český Těšín residents. The Municipal Library in Český Těšín was visited multiple times by $20.71 \%$ of respondents, and the Těšín Theatre—by $20.06 \%$ of the respondents.

Table 3. The frequency at which inhabitants of the Polish and Czech sides of the city take advantage of the offerings of Cieszyn's cultural institutions and entities in 2017 [in \%].

\begin{tabular}{|c|c|c|c|c|c|c|c|c|}
\hline \multirow[b]{2}{*}{ Specification } & \multicolumn{4}{|c|}{ Inhabitants of the Polish Side of the City (PL) N $=490$} & \multicolumn{4}{|c|}{ Inhabitants of the Czech Side of the City $(\mathrm{CZ}) \mathrm{N}=309$} \\
\hline & Not Once & $\begin{array}{l}\text { Once or } \\
\text { Twice }\end{array}$ & $\begin{array}{l}\text { Three or } \\
\text { Four Times }\end{array}$ & $\begin{array}{l}\text { More Than } \\
\text { Four Times }\end{array}$ & $\begin{array}{l}\text { Not } \\
\text { Once }\end{array}$ & $\begin{array}{l}\text { Once or } \\
\text { Twice }\end{array}$ & $\begin{array}{c}\text { Three or } \\
\text { Four Times }\end{array}$ & $\begin{array}{l}\text { More Than } \\
\text { Four Times }\end{array}$ \\
\hline $\begin{array}{l}\text { Cieszyn's cultural } \\
\text { entities (PL) }\end{array}$ & 69.27 & 17.58 & 6.48 & 6.67 & 84.16 & 10.81 & 2.84 & 2.19 \\
\hline $\begin{array}{l}\text { Český Těšín's cultural } \\
\text { entities (CZ) }\end{array}$ & 88.66 & 7.12 & 2.29 & 1.94 & 51.13 & 22.98 & 12.82 & 13.07 \\
\hline
\end{tabular}

Source. Own study based on the research results.

The issue of the familiarity and participation of residents in selected cultural events organised in Cieszyn and Český Těšín was also examined. The results, broken down into cultural events, which were implemented as part of Euroregional cross-border projects, and those that were implemented without financial support received through the Euroregion, are presented in Table 4.

Table 4. The familiarity and participation of residents in the most important events, cultural undertakings taking place on the Polish and Czech side of the city [in \%].

\begin{tabular}{lcccc}
\hline \multicolumn{1}{c}{ Specification } & \multicolumn{2}{c}{$\begin{array}{c}\text { Inhabitants of the Polish Side } \\
\text { of the City (PL) } \mathbf{N}=\mathbf{4 9 0}\end{array}$} & \multicolumn{2}{c}{$\begin{array}{c}\text { Inhabitants of the Czech Side } \\
\text { of the City (CZ) } \mathbf{N}=\mathbf{3 0 9}\end{array}$} \\
\cline { 2 - 5 } & Familiarity & Participation & Familiarity & Participation \\
\hline $\begin{array}{l}\text { Cultural events taking place in Cieszyn and Český } \\
\begin{array}{l}\text { Těšín without financial support received through } \\
\text { the Cieszyn Silesia Euroregion }\end{array}\end{array}$ & 32.27 & 11.40 & 20.07 & 3.06 \\
\hline $\begin{array}{l}\text { Cultural events taking place in Cieszyn and Český } \\
\text { Těšín as part of Euroregional cultural projects }\end{array}$ & 73.76 & 43.02 & 58.51 & 31.97 \\
\hline
\end{tabular}

The results do not add up to 100, because respondents had the option of selecting more than one answer. Source. Own study based on the research results.

The data presented in Table 4 shows that the level of familiarity with cultural events organised in Cieszyn and Český Těšín within the framework of Euroregional cross-border projects is much higher than the familiarity with cultural events that are organised without financial support received through the Cieszyn Silesia Euroregion, and thus without the requirement of having an impact on the other side of the border.

This may be confirmed by the fact that nearly $74 \%$ of the surveyed residents of Cieszyn, and $59 \%$ of the residents of Český Těśn, claim that they are familiar with specific cultural events mentioned in the questionnaire (assisted knowledge), events taking place as part of Euroregional cross-border projects. The events implemented without financial support received via the Cieszyn Silesia Euroregion had a definitely worse result. Events of this type are usually organised by Polish or Czech cultural entities independently, without consulting a partner on the other side of the border, and their promotion is usually limited only to the country in which the entity organising the event is located. Respondents were also asked to indicate the events and cultural undertakings in which they participated. As in the case of the previous question, a significantly larger part of Cieszyn and Český Těšin inhabitants participated in cultural events that were implemented as part of Euroregional cross-border projects (Cieszyn inhabitants 43.02\%, Český Těšín inhabitants 31.97\%) than in events, which did not receive funding from European Union funds through the Cieszyn Silesia Euroregion 
(Cieszyn inhabitants-11.45\%, Český Těšín inhabitants-8.06\%). The data presented in Table 4 also shows that Polish respondents are better acquainted with the cultural offerings of Cieszyn/Český Těšín than their Czech neighbours living on the other side of the border.

\subsection{Conclusions from Qualitative Research—Study of the Supply Side of the Market}

The next stage of the research included qualitative research, which was conducted by the interview method using an interview questionnaire (40 individual in-depth interviews). The interviewed experts were asked to indicate changes in the cultural offerings which, in their opinion, could contribute to the sustainable development of the cross-border market for cultural services in Cieszyn and Český Těšín. The vast majority of experts stated that in order for such a development to be possible, the coordination of activities carried out in both cities by cultural departments located on both sides of the border needed to be improved. According to some of the respondents (18 experts), the cultural departments of both cities should focus more on the coordination of activities carried out by local government cultural institutions, as well as assist these institutions in promoting the cultural offerings on the other side of the border. According to 12 experts, both local government units should organise regular meetings, during which all directors of cultural institutions could regularly meet representatives of municipal cultural institutions on the other (foreign) side of the city, to establish a common calendar of cultural events, or make strategic decisions regarding the further development of the cultural sector in both cities. At the same time, most of the experts surveyed considered that this required a common cross-border cultural policy that currently does not exist (32 experts). As part of this policy, the authorities of both cities should clearly specify what they expect from cultural institutions located on both sides of the city divided by a border. For example, should the cultural offerings follow the expectations of the majority of residents, and be even more commercial (closer to entertainment), or should it be more ambitious, more saturated with artistic content (which, however, is associated with greater financial outlays, and definitely more intensive cultural education than before). In the opinion of the respondents, the cultural policy in Cieszyn and Český Těšín has been reduced to managing cultural institutions or simply administering them, while it should be based on an understanding of the mechanism of the so-called 'value creation chain' in culture. According to experts, we have to stop looking at culture only in a sectoral way, and start to treat the potential of the cultural institutions of Cieszyn and Český Těšn as capital that significantly affects the socio-economic development of both cities and the region. It is also necessary to answer the question whether both cities want to develop a cross-border market for cultural services in Cieszyn and Český Těšín, or only to maintain their current status. Sustainable development of the cross-border market for cultural services, according to experts, requires shared, regular, long-term and often costly, activities (even in terms of shared marketing communication for the inhabitants of both cities), and not only the incidental activities which are carried out, for example, on the occasion of joint municipal holidays. The problem of municipal and inter-city transport has also been raised. The respondents pointed out that in Cieszyn and Český Těšín there is not a single public transport line that connects the two cities.

The joint promotion of Polish and Czech cultural institutions, a joint public transport line connecting the two cities, emphasis on the cross-border nature of both cities-could significantly contribute to the "fading away of the border", and the sustainable development of the cross-border market for cultural services.

The surveyed experts were also asked whether cultural institutions cooperate with cultural entities, institutions, and organisations on the other side of the border. The vast majority of respondents (31 experts) stated that the institutions they represent cooperate with cultural organisations on the other side of the border. This cooperation is both very formal (e.g., in the implementation of joint Euroregional cross-border projects, co-financed by EU funds), and less formal (the organisation of joint cultural events, consultations or social events). The institutions most often look for partners with a similar profile on the other side of the border (for example, the Municipal Public Library in Cieszyn, and the Municipal Public Library in Český Těšín). The vast majority of respondents (37 people) stated 
that the main benefits (apart from the issues of acquiring cross-border funds) from the cooperation of cultural institutions from Cieszyn and Český Těšín are, of course, joint cross-border cultural events, such as: The "Cinema on the Border" Film Festival, or the "Without Borders" International Theatre Festival. An additional benefit associated with the organisation of cross-border cultural events, is the joint Polish-Czech promotion. It leads to "opening the door", giving a pretext to the inhabitants, i.e., the audience on both sides of the divided city, to cross the border. An undoubted benefit of cooperation between Polish and Czech cultural institutions is building awareness among the residents of both cities that culture is a shared value; it is what unites and enriches us. The potential of Cieszyn and Český Těšín lies in its unity. Thanks to the cooperation of cultural institutions on both sides of the border, we can count on the synergy effect and build a joint brand that will be recognisable, not only in Poland and the Czech Republic, but also in Europe. The respondents also pointed out such benefits as building mutual trust, breaking "mental borders", transfer or exchange of knowledge and experience, the ability to use shared staff or infrastructure, which is located on the other side of the border. An undoubted benefit is the ability to exchange the audience. Tourists who visit Český Těšín can also be guided through Cieszyn by organisers, and encouraged to visit the cultural institutions that are located there.

At the same time, the respondents pointed out the weaknesses of the cross-border cooperation of cultural institutions located in Cieszyn and Český Těšín. The main barrier in cross-border cooperation is the language barrier, which, in the opinion of the respondents, undoubtedly exists. The respondents also pointed to functioning stereotypes, different perceptions of history, the continuous deficit of mutual trust, the different understanding of community and/or culture by Poles and Czechs. The weak point of cross-border cooperation is the different pace of work on both sides of the border, which can sometimes be annoying for partners on either side, and the fact that "the responsibility in the area of organisation, finances or details always lies on the Polish side". Other aspects which were indicated included various financing options, different conditions for co-financing cultural projects for cultural institutions in both countries, as well as legal difficulties, for example, the lack of free movement for organised class trips from the Polish side to events organised on the Czech side (the need to purchase additional insurance for pupils, consent of the Board of Education).

Despite the weaknesses which were mentioned, the majority of the experts surveyed (36 out of 40 people) stated that the cooperation of cultural institutions from Cieszyn and Český Těšín is at a good level. Some respondents even claimed that there is no need to intensify it even more, although the majority of respondents recognised that the cooperation of cultural institutions should develop more extensively. Suggested areas of improvement mainly included a joint cultural education, a joint Polish-Czech promotion of the organised cultural events, a joint calendar of events, or shared public transport. Attention was also paid to better coordination of cross-border activities. Currently, coordination takes place mainly at national levels (separately on the Polish and Czech side). There is no coordination at the transnational, cross-border level.

\section{Discussion}

The interviews conducted with representatives of the Polish and Czech sides of the Cieszyn Silesia Euroregion indicate that the Euroregion's activities, stimulating the sustainable development of the cross-border market for cultural services in the city divided by a border, most often consist of:

- Support for cultural entities located in Cieszyn and Český Těšín, as well as in the area of the Cieszyn Silesia Euroregion in initiating Polish-Czech partnerships that lead, among others, to the carrying out of cross-border projects in the area of culture that enrich the supply in the cross-border market for cultural services (e.g., by organising so-called 'partnership markets' dedicated to institutions in the cultural sector);

- Consultancy in searching for the best source of financing for cross-border projects in the area of culture. Such projects, in the opinion of the surveyed representatives of the Cieszyn Silesia Euroregion, can be implemented using many sources of financing, which include not only 
the Interreg VA Czech Republic-Poland programme, including the Micro-Projects Fund of the Cieszyn Silesia Euroregion, but also Interreg Central Europe (2014-2020), Interreg Europa Programme 2014-2020, International Visegrad Fund, Europe for Citizens Programme, and the Erasmus+ Programme;

- Supporting cultural institutions in the implementation of cross-border cultural projects, for example through promotional support of these events (patronage, running an internet website "Culture in the Region");

- Implementation of cross-border projects aimed at the sustainable development of the Polish-Czech cross-border market for cultural services, or shaping a joint cross-border cultural policy (e.g., the "Český Těšín/Cieszyn InEurope" project);

- Conducting research and scientific activity regarding the prospects for further sustainable development of the cross-border market for cultural services, e.g., as part of the established Polish-Czech-Slovak EuroInstitute (development of concept documents, programmes and strategies);

- Conducting training and publishing activities aimed at presenting research results on cross-border cooperation, including the area of culture (e.g., "Work of the Polish-Czech-Slovak EuroInstitute TRANSCARPATHICA" published on a regular basis by the Polish side of the Cieszyn Silesia Euroregion).

Similar areas of activity supporting the development of cross-border cooperation in the area of culture were also indicated by Castanho et al., who conducted research on the conditions of the functioning of Eurocities on the Portuguese-Spanish border [46,47].

The conducted research also made it possible to define activities that, in the opinion of the authors, should allow for the strengthening of cross-border cooperation in the area of culture. This means cooperation both in the inter-organisational dimension (at the level of cultural institutions), and in the personnel dimension (at the level of cooperation between individual employees). Based on the results of research conducted by Kurowska et al. [48-51], Böhm [52,53] and Suchacka et al. [54,55], carried out in the area of the Cieszyn Silesia, Silesia and Beskidy Euroregions, as well as on the results of the authors' own research, the authors concluded that intensification of cross-border cooperation in the area of culture aimed at sustainable development of the cross-border market for cultural services in Cieszyn and Český Těšín should take place:

- At various levels (between local governments of both cities, local government cultural institutions, non-governmental organisations, individual creators or residents);

- In various thematic areas (e.g., joint improvement of staff, joint promotion of culture, joint marketing activities, joint bilingual cultural offer, etc.);

- In the formal dimension (e.g., as official contacts between institutions) and in the informal dimension (e.g., contacts of informal groups, non-official relations, social relations, etc.);

- Through better mutual understanding (e.g., learning the neighbour's language, regular consultative meetings);

- By implementing joint policy (e.g., including analogous cultural tasks in the budgets of both cities, joint micro-grants for the development of cross-border cooperation between informal groups and associations, guidelines for joint strategies and programmes for cultural development in both cities, etc.).

These activities are necessary to create varied, attractive, diverse and sustainable cultural offerings, corresponding to the authentic cultural needs of residents and people visiting Cieszyn and Český Těšín. This will prevent the dispersion of funds and resources, and excessive fragmentation of activities in the area of culture [56-58]. In the opinion of Polish and Czech experts, the activity of the Cieszyn Silesia Euroregion corresponds very well with the principles of a joint cross-border cultural policy, supporting the sustainable development of the cross-border market for cultural services in European cities divided by a border. These activities should be based primarily on: 
- Joint cultural education, which determines the level of cultural competence of the inhabitants of the divided city, balances the differences between residents on both sides of the border;

- Stimulating the activity of local cultural institutions, non-governmental organisations and local communities in popularising and sharing cultural goods;

- Supporting cultural freedom, including the freedom of artistic expression;

- Supporting cross-border cultural events, among others via European Union programmes;

- Engaging expert and advisory teams, initiating public discussions in order to increase the socialisation of decision-making processes related to solving key problems regarding the functioning of the cross-border market for cultural services;

- Moving away from the peripheral position of culture in local government administration; culture linked with other fields should be maintained at regional, cross-border and local level.

According to experts participating in the consultative meeting in Český Těšín, the joint cultural policy of the city divided by a border requires the further support of the Euroregion. This support should include:

- The culture on both sides of the border being on an equal level, both the culture of one's own country, and the culture of the neighbouring country;

- Artistic creation in the broadest sense and the reception of this work-and therefore interest in the functioning of institutions both serving this creativity and making it available. This applies both to the creativity associated with art (so-called 'high culture'), and to that belonging to the sphere of entertainment and recreation (so-called 'mass culture');

- The functioning of joint cross-border mass media-in particular local and regional press, websites, radio. We shouldn't forget that in the 21st century mass media is not only an important marketing instrument, but increasingly, an educational instrument supporting the culture of the cross-border region, knowledge of symbols functioning therein, and finally enriching the knowledge, attitudes and life orientations of local communities on both sides of the border;

- The social functioning of artistic culture-including: Non-professional and amateur creativity;

- Not only artistic culture, but also the valuable culture and the aesthetics of everyday life, socially desirable customs, work culture, the culture of public life, home culture;

- Incorporating the culture of the neighbouring country, as well as European and world culture, both into the joint culture of the region, and the national culture.

In summary, the surveyed experts stated that the joint cultural policy of the city divided by a border, supported by local governments, regional authorities and the Euroregion, encourages the development of cultural democracy and a civil society, making it easier for creators and cultural institutions to penetrate the market-based economy, protect the greatest cultural values, and, finally, introducing and initiating legislative solutions favouring new forms of activity.

\section{Conclusions}

The current geopolitical situation of Poland and the Czech Republic creates a good climate for the activities and effectiveness of both the Euroregions on the Polish-Czech border, and other Euroregions in the European Union. Entering EU structures and then entering the Schengen Area definitely facilitates cooperation opportunities in the area of culture. The European Union facilitates the functioning of Euroregions through the level of resources allocated to border areas. The quantitative and qualitative research carried out indicates that Euroregions, focusing on cross-border cooperation in the area of culture, support the process of local and often regional development of the cross-border market for cultural services. The presented results shows that the level of familiarity with cultural events organised in Cieszyn and Český Těšín within the framework of Interreg cross-border projects, is much higher than the familiarity with cultural events that are organised without financial support received through the Cieszyn Silesia Euroregion. Thus, as assumed by the hypothesis adopted, the 
Euroregion stimulates the sustainable development of the cross-border market for cultural services in a city divided by a border - such as Cieszyn and Český Těšín. At the same time, it should be remembered that the effectiveness of the Euroregion in stimulating this development cannot be assessed only through the prism of projects carried out in the area of culture. As Sitek noted [59], acting in accordance with the principle that the implementation of a project corresponds to the possibility of obtaining funds, is far from sufficient. The Euroregion must constantly monitor the cultural needs of the residents of the city divided by a border, or the entire region, and verify the effects of the cross-border projects implemented. The activities of scientific and research institutions, which conduct regular research in this area on the initiative, and with the support of the Euroregion, may be helpful in these efforts. Examples of such institutions include the Polish-Czech-Slovak EuroInstitute operating within the Cieszyn Silesia Euroregion, the Commission on Polish-Czech and Polish-Slovak Relations at the Katowice Branch of the Polish Academy of Sciences cooperating with the Euroregion, and the Institute for Territorial and Inter-Organisational Cooperation Research at the WSB University established in Cieszyn.

Of course, the above considerations do not exhaust the problem, rather, they are only a modest contribution to further research. Cities divided by an international border in Europe ("Type $C$ " and "Type D", see Figure 1) constitute a very heterogeneous category, which is internally diverse in many respects. As Zenderowski noted [22] in many cases, the only element connecting them with each other is the fact that there is an international border dividing the city into two parts. Therefore, the results and research conclusions presented in the article cannot be generalised to all cities divided by a border. They may, however, be a good starting point for developing a joint cross-border cultural policy in cities that, like Cieszyn and Český Těšín, are located in the European Union and the Schengen Area. The next step is to conduct similar research in the so-called neighbouring and connected cities ("Type A" and "Type B") of the European Union, or in cities located on the external border of the European Union. The examination of various case studies and viewpoints should contribute more fully to the explanation of the phenomenon described.

Author Contributions: Ł.W. and A.K. contributed equally in the development of the present paper. For the proper paper developing, all the phases have been discussed and worked by Ł.W. and A.K.

Funding: The research carried out was part of two Polish-Czech cross-border projects co-financed by the European Regional Development Fund-Interreg V-A Programme Czech Republic-Poland as part of the Micro-Projects Fund of the Cieszyn Silesia Euroregion-Těšínské Slezsko and the state budget.

Acknowledgments: The authors would like to thank the representatives of the Polish and Czech side of the Cieszyn Silesia Euroregion and all Polish and Czech experts who took part in the study for their time, materials provided, and comprehensive answers to questions.

Conflicts of Interest: The authors declare no conflict of interest.

\section{Appendix A}

Table A1. The socio-demographic description of surveyed inhabitants of the Polish and Czech side of the city [in \%].

\begin{tabular}{lcc}
\hline \multicolumn{1}{c}{ Specification } & $\begin{array}{c}\text { Inhabitants of the Polish } \\
\text { Side of the City (PL) N = 490 }\end{array}$ & $\begin{array}{c}\text { Inhabitants of the Czech Side } \\
\text { of the City (CZ) N = 309 }\end{array}$ \\
\hline \multicolumn{2}{c}{ Sex } \\
\hline Female & 65.92 & 67.64 \\
Male & 34.08 & 32.36 \\
\hline \multicolumn{2}{c}{ Age } \\
\hline Under 18 & 13.47 & 3.56 \\
18-24 & 21.02 & 33.66 \\
25-34 & 20.20 & 13.59 \\
45-44 54 & 21.43 & 18.77 \\
55-64 & 9.80 & 13.27 \\
Over 64 & 9.79 & 9.06 \\
\hline
\end{tabular}


Table A1. Cont.

\begin{tabular}{lcc}
\hline Specification & $\begin{array}{c}\text { Inhabitants of the Polish } \\
\text { Side of the City (PL) N = 490 }\end{array}$ & $\begin{array}{c}\text { Inhabitants of the Czech Side } \\
\text { of the City (CZ) N = 309 }\end{array}$ \\
\hline \multicolumn{2}{c}{ Education } \\
\hline Primary & 15.71 & 23.85 \\
Secondary & 6.33 & 12.62 \\
In college & 39.59 & 34.64 \\
Higher education & 38.37 & 28.89 \\
\hline
\end{tabular}

\section{Appendix B}

Table A2. Experts participating in the in-depth interviews.

\begin{tabular}{|c|c|c|}
\hline \multirow{2}{*}{ Item } & \multicolumn{2}{|c|}{ Experts Participating in the Research (IDI-in-Depth Interviews) } \\
\hline & Experts on the Polish Side (Cieszyn) & Experts on the Czech Side (Český Těšín) \\
\hline 1 & Director of the Cieszyn Castle & Director of the Youth Centre in Český Těšín \\
\hline 2 & Director of the Cieszyn Cultural Centre "Dom Narodowy" & Director of Albrechtova střední škola Český Těšín \\
\hline 3 & Director of the Cieszyn Library & $\begin{array}{l}\text { Director of the Association "Człowiek na Granicy" (Man } \\
\text { on the Border) in Český Těšín }\end{array}$ \\
\hline 4 & Director of the Adam Mickiewicz Theatre in Cieszyn & $\begin{array}{l}\text { Deputy Director, coordinator of cultural projects } \\
\text { Mateřská škola, základní škola a střední škola } \\
\text { Slezské diakonie }\end{array}$ \\
\hline 5 & Director of the Municipal Library in Cieszyn & $\begin{array}{l}\text { Vice-President, project manager in the Polish Youth } \\
\text { Association in the Czech Republic - club „Dziupla" in } \\
\text { Český Těšín }\end{array}$ \\
\hline 6 & Director of the Museum of Cieszyn Silesia & $\begin{array}{l}\text { Project coordinator, organisational employee of Otwarte } \\
\text { Pracownie/Otevřené Ateliéry }\end{array}$ \\
\hline 7 & $\begin{array}{l}\text { Director of the Festival "Viva il Canto", Associate Dean for } \\
\text { Promotion and Artistic Activities of the University of Silesia, } \\
\text { Faculty of Fine Arts in Cieszyn }\end{array}$ & $\begin{array}{l}\text { Employee of the Literary Cafe "CAFE AVION" in } \\
\text { Český Tešín }\end{array}$ \\
\hline 8 & $\begin{array}{l}\text { Head of the Cultural Education Department in the Faculty of } \\
\text { Ethnology and Educational Science of the University of Silesia, } \\
\text { Branch in Cieszyn }\end{array}$ & $\begin{array}{l}\text { Member of the Association EducationTalentCulture } \\
\text { based in in Český Těšín }\end{array}$ \\
\hline 9 & $\begin{array}{l}\text { President of the Polish Cultural and Educational Union in the } \\
\text { Czech Republic }\end{array}$ & Theatre director, artist of the Theatre in Český Těšín \\
\hline 10 & $\begin{array}{l}\text { President of the Association „'Kultura na Granicy” (Culture on } \\
\text { the Border), Director of the Film Festival PL „Kino na Granicy” } \\
\text { (Cinema on the Border) }\end{array}$ & $\begin{array}{l}\text { Member of the Cultural Committee of the town of } \\
\text { Český Tešín }\end{array}$ \\
\hline 11 & $\begin{array}{l}\text { Secretary of the Polish-Czech-Slovak Solidarity, Regional } \\
\text { Branch in Cieszyn }\end{array}$ & $\begin{array}{l}\text { Coordinator of the Polish-Czech projects in the Prida } \\
\text { Association in Český Těšín }\end{array}$ \\
\hline 12 & $\begin{array}{l}\text { Head of the Culture, Sports, Tourism and NGO Department of } \\
\text { the Poviat Starosty in Cieszyn }\end{array}$ & $\begin{array}{l}\text { Head of the PR Department, Spokesperson of the } \\
\text { Muzeum Těšínska in Český Těšín }\end{array}$ \\
\hline 13 & Director of the "Na Granicy" Political Critique Centre & $\begin{array}{l}\text { Coordinator of the Polish-Czech projects in the } \\
\text { Municipal Library in Český Těšín }\end{array}$ \\
\hline 14 & Director of the Museum of Printing in Cieszyn & Animator of the Cultural Centre Slezanek, Český Těšín \\
\hline 15 & $\begin{array}{l}\text { President of the Management Board of the Creative Women's } \\
\text { Club in Cieszyn }\end{array}$ & Animator of the Youth Centre in Český Těšín \\
\hline 16 & $\begin{array}{l}\text { Manager of Polish-Czech projects in the Polish Cultural and } \\
\text { Educational Union in the Czech Republic }\end{array}$ & Culture referent in the town of Český Těšín \\
\hline 17 & Journalist of „Głos" - Polish newspaper in the Czech Republic & Director of the Project „Every Czech Reads to Kids” \\
\hline 18 & Member of the Main Board of Macierz Ziemi Cieszyńskiej & $\begin{array}{l}\text { Director of the Association "Asociace obecne } \\
\text { prospěšných služeb" in Český Těšín }\end{array}$ \\
\hline 19 & Treasurer of the "Rotunda" Association in Cieszyn & $\begin{array}{l}\text { Coordinator of cultural projects in the Cultural Centre } \\
\text { "Střelnice" in Český Těšín }\end{array}$ \\
\hline 20 & President of the OFKA Social Cooperative in Cieszyn & PR manager in the town of Český Těšín \\
\hline
\end{tabular}




\section{References}

1. Heinelt, H.; Niederhafner, S. Cities and Organized Interest Intermediation in the EU Multi-Level System. Eur. Urban Reg. Stud. 2008, 15, 173-187. [CrossRef]

2. Gualini, E. Cross-border Governance: Inventing Regions in a Trans-national, Multi-level Polity. DisP-Plan. Rev. 2003, 39, 43-52. [CrossRef]

3. Schulz, H. Twin Towns on the Border as Laboratories of European Integration; University of Viadrina: Frankfurt Oder, Germany, 2002.

4. Swyngedouw, E. Scaled geographies: Nature place and the politics of scale. In Scale and Geographic Inquiry; Sheppard, E., McMaster, R., Eds.; Blackwell: Oxford, UK, 2004.

5. Newman, D. Borders and bordering: Towards an interdisciplinary dialogue. Eur. J. Soc. Theory 2006, 9, 171-186. [CrossRef]

6. Ehlers, N.; Buursink, J. Binational Cities: People, Institutions, and Structures. In Borders, Regions, and People; van der Velde, M., van Houtum, H., Eds.; Pion Ltd.: London, UK, 2000.

7. Buursink, J. The binational reality of border-crossing cities. Geojournal 2001, 54, 7-19. [CrossRef]

8. Harvey, D.C. Divided Cities: Belfast, Beirut, Jerusalem, Mostar, and Nicosia by Jon Calame and Esther Charlesworth. Soc. Without Bord. 2012, 7, 380-384.

9. Joenniemi, P.; Sergunin, A. When two aspire to become one: City-twinning in Northern Europe. J. Borderl. Stud. 2011, 26, 231-242. [CrossRef]

10. Vandamme, F. Labour Mobility within theEuropean Union: Findings, Stakes and Prospects. Int. Labour Rev. 2000, 139, 437-455. [CrossRef]

11. Van Houtum, H. Borders of Comfort: SpatialEconomic Bordering Processes on and by the European Union. Reg. Fed. Stud. 2002, 12, 37-58. [CrossRef]

12. Strüver, A. Significant Insignificance: Boundaries in a Borderless European Union-Deconstructing the Dutch-German Transnational Labour Market. J. Borderl. Stud. 2002, 17, 21-36. [CrossRef]

13. Dołzbłasz, S.; Raczyk, A. Transborder openness of companies in a divided city: Zgorzelec/Görlitz Case study. Tijdschr. Econ. Soc. Geogr. 2012, 103, 347-361. [CrossRef]

14. Atun, R.A.; Doratli, N. Walls in Cities: A Conceptual Approach to the Walls of Nicosia. Geopolitics 2009, 14, 108-134. [CrossRef]

15. Dębicki, M.; Tamáska, M. Laboratories of integration. Divided twin towns at river borders in the Visegrad Countries and Germany. Socio.Hu Spec. Visegr. Issue 2014, 2, 1-20.

16. Burghardt, A.F. A hypothesis about gateway cities. Ann. Assoc. Am. Geogr. 1971, 61, 269-285. [CrossRef]

17. Brańka, T. Tornio-Haparanda. A Unique Result of Neighboring Town's Collaboration. In Conflict and Cooperation in Divided Cities; Jańczak, J., Ed.; Logos Verlag: Berlin, Germany, 2009; pp. 191-204.

18. Dołzbłasz, S. Cross-border co-operation in the Euroregions at the Polish-Czech and Polish-Slovak borders. Eur. Ctry. 2013, 5, 102-114. [CrossRef]

19. Jańczak, J. Gorizia-Nova Gorica. Between Unification and Reunification. In Conflict and Cooperation in Divided Cities; Jańczak, J., Ed.; Logos Verlag: Berlin, Germany, 2009; pp. 122-132.

20. Kulczyńska, K. The Gubin-Guben transborder urban complex as an arena of consumer behaviour. Bull. Geography. Socio-Econ. Ser. 2010, 14, 79-89. [CrossRef]

21. Jańczak., J. (Ed.) Conflict and Cooperation in Divided Cities; Logos Verlag: Berlin, Germany, 2009.

22. Zenderowski, R.; Brzezińska, M. Miasta podzielone granica państwowa w nowych państwach członkowskich UE: Od separacji do integracji. Pogranicze. Pol. Borderl. Stud. 2014, 2, 164-183.

23. Pietroszek, K. Historical Towns Divided by International Border Rivers-The Way to Cooperation and Integration; University of Waterloo: Waterloo, UK, 2009.

24. Wróblewski, Ł. Structure and conditions for the functioning of the Polish-Czech cross-border market of cultural service. Ekon. Vjesn. 2018, 31, 371-384.

25. Dacko-Pikiewicz, Z.; Wróblewski, Ł. Spatial range of the influence of the philharmonic institutions in Katowice. Forum Sci. Oecono. 2017, 5, 17-34.

26. Wróblewski, Ł.; Dziadzia, B.; Dacko-Pikiewicz, Z. Sustainable Management of the Offer of Cultural Institutions in the Cross-Border Market for Cultural Services-Barriers and Conditions. Sustainability 2018, 10, 3253. [CrossRef]

27. Wróblewski, Ł. Cultural Management. Strategy and Marketing Aspects; Logos Verlag: Berlin, Germany, 2017. 
28. Sobocińska, M. Management of value for customers on the culture market. Int. J. Bus. Perform. Manag. 2015, 16, 262-279. [CrossRef]

29. Kędzior, Z. (Ed.) Badania Rynku-Metody, Zastosowania; PWE: Warsaw, Poland, 2005.

30. Perkmann, M. Cross-Border Regions in Europe: Significance and Drivers of Regional Cross-Border Co-Operation. Eur. Urban Reg. Stud. 2003, 10, 153-171. [CrossRef]

31. Wróblewski, Ł.; Kurowska-Pysz, J.; Dacko-Pkiewicz, Z. Polish-Czech micro-projects as a tool for shaping consumer behaviour on the cross-border market for cultural services. In Innovation Management and Education Excellence through Vision 2020, Proceedings of the 31st International Business Information Management Association Conference, Milano, Italy, 25-26 April 2018; Soliman, K.S., Ed.; International Business Information Management Association: Milan, Italy, 2018; pp. 3131-3141.

32. Kasperek, B. (Ed.) Euroregiony Pogranicza Polsko-Czeskiego-Euroregiony Polsko-Českého Pohraničí Stowarzyszenie Rozwoju i Współpracy Regionalnej “Olza”: Cieszyn, Poland, 2014.

33. Kurowska-Pysz, J. Opportunities for Cross-Border Entrepreneurship Development in a Cluster Model Exemplified by the Polish-Czech Border Region. Sustainability 2016, 8, 230. [CrossRef]

34. Olszewski, M. The Benefits and Challenges for Cross Border Cooperation in the Cieszyn Silesia Euroregion. J. Cross Bord. Stud. Irel. 2016, 11, 40-56.

35. Lepik, K.L. Euroregions as mechanisms for strengthening cross-border cooperation in the Baltic Sea Region. Trames J. Humanit. Soc. Sci. 2009, 13, 265-284. [CrossRef]

36. Böhm, H. Czech-Polish Borders: Comparison of the EU Funds for Cross-Border Co-Operation of Schools in All Czech-Polish Euroregions; Civilia, Palacky University Olomouc: Olomous, Czech Republic, 2016.

37. Klatt, M.; Wassenberg, B. Secondary foreign policy: Can local and regional cross-border cooperation function as a tool for peace-building and reconciliation? Reg. Fed. Stud. 2017, 27, 205-218. [CrossRef]

38. Kurowska-Pysz, J. Partnership Management in Polish-Czech Micro-Projects in Euroregion Beskidy. In Economic Policy in the European Union Member Countries; Silesian University: Karvina, Czech Republic, 2016.

39. Hooper, B.; Kramsch, O. (Eds.) Cross-Border Governance in the European Union; Routledge: London, UK, 2004.

40. Wróblewski, Ł. The Influence of Creative Industries on the Socioeconomic Development of Regions in Poland. Int. J. Entrep. Knowl. 2014, 1, 45-57. [CrossRef]

41. Kasperek, A. Culture as a space of reconciliation through transborder cooperation. The case of project activeness implemented within the activity of Cieszyn Silesia Euroregion. In Cultural Management. From Theory to Practice; Wróblewski, Ł., Dacko-Pikiewicz, Z., Liu, J.C.Y., Eds.; London Scientific: London, UK, 2018; pp. 131-145.

42. Rusek, H.; Kasperek, A. Memory sites versus antagonism and reconciliation-the case of Polish-Czech relations. In Reconciliation in Bloodlands. Assessing Actions and Outcomes in Contemporary Central Eastern Europe; Kurczewski, J., Ed.; Peter Lang Edition: Frankfurt am Main, Germany, 2014; pp. 195-213.

43. Rezolucja Sejmu Rzeczypospolitej Polskiej z Dnia 2 Marca 1999. Available online: http:/ / prawo.sejm.gov.pl/ isap.nsf/download.xsp/WMP19990080096/O/M19990096.pdf (accessed on 30 January 2019).

44. Kurczewski, J. (Ed.) Reconciliation in Bloodlands. Assessing Actions and Outcomes in Contemporary Central Eastern Europe; Peter Lang Edition: Frankfurt am Main, Germany, 2014.

45. Wróblewski, Ł. Websites of Polish cultural and educational organizations in the Czech Republic-Analysis and evaluation. Forum Sci. Oecon. 2015, 3, 65-78.

46. Castanho, R.A.; Naranjo Gómez, J.M.; Kurowska-Pysz, J. How to Reach the Eurocities? A Retrospective Review of the Evolution Dynamics of Urban Planning and Management on the Iberian Peninsula Territories. Sustainability 2019, 11, 602. [CrossRef]

47. Castanho, R.A.; Vulevic, A.; Fernández, J.C.; Fernández-Pozo, L.; Gómez, J.M.N.; Loures, L.C. Accessibility and connectivity-Movement between cities, as a critical factor to achieve success on cross-border cooperation (CBC) projects. A European analysis. Sustain. Cities Soc. 2017, 32, 181-190. [CrossRef]

48. Kurowska-Pysz, J.; Gregor, M. The transfer of knowledge in technological cross-border industry cluster-Case study. Manag. Syst. Prod. Eng. 2014, 2, 63-67.

49. Kurowska-Pysz, J.; Wróblewski, Ł.; Szczepańska-Woszczyna, K. Identification and assessment of barriers to the development of cross-border cooperation. In Innovation Management and Education Excellence through Vision 2020, Proceedings of the 31st International Business Information Management Association Conference, Milano, Italy, 25-26 April 2018; Soliman, K.S., Ed.; International Business Information Management Association: Milan, Italy, 2018; pp. 3317-3327. 
50. Kurowska-Pysz, J. Assessment of trends for the development of cross border cultural clusters. Forum Sci. Oecon. 2015, 3, 31-43.

51. Greblikaitè, J.; Sroka, W.; Daugèlienè, R.; Kurowska-Pysz, J. Cultural integration and cross-cultural management challenges in the Central European Countries: Lithuania and Poland. Eur. Integr. Stud. 2016. [CrossRef]

52. Böhm, H.; Drápela, E. Cross-border Cooperation as a Reconciliation Tool: Example from the East Czech-Polish Borders. Reg. Fed. Stud. 2017, 27, 305-319. [CrossRef]

53. Böhm, H. A Comparison of Governance forms For Cross-border Co-operation within the EU. J. Cross-Bord. Stud. 2014, 9, 79-91.

54. Suchacek, J.; Seda, P.; Friedrich, V. Size and Regional Varieties of Communal Marketing in the Czech Republic. Pol. J. Manag. Stud. 2017, 15, 262-272. [CrossRef]

55. Sucháček, J.; Walancik, M.; Wróblewski, Ł.; Urminský, J.; Drastichová, M.; Šotkovski, I. Management of Municipal Development of Euroregion Beskydy in Poland and Czechia. Pol. J. Manag. Stud. 2018, 18. [CrossRef]

56. Wróblewski, Ł. Creating an image of a region-Euroregion Beskydy and Euroregion Cieszyn Silesia examples. Econ. Manag. 2016, 8, 91-100. [CrossRef]

57. Anderson, J. Democracy: Political Changes and Border Crossings; Publisher Routledge: London, UK, 2002.

58. Wróblewski, Ł.; Howaniec, H. New trends in consumer behaviour in the market of cultural services in Poland: Implications for marketing. Cult. Manag. Sci. Educ. 2018, 2, 67-83. [CrossRef]

59. Sitek, S. Współpraca transgraniczna w ramach euroregionów na pograniczu polsko-czeskim. In Euroregiony Pogranicza Polsko-Czeskiego-Euroregiony Polsko-Českého Pohraničí; Kasperek, B., Ed.; Stowarzyszenie Rozwoju i Współpracy Regionalnej “Olza”: Cieszyn, Poland, 2014; pp. 8-33.

(C) 2019 by the authors. Licensee MDPI, Basel, Switzerland. This article is an open access article distributed under the terms and conditions of the Creative Commons Attribution (CC BY) license (http:/ / creativecommons.org/licenses/by/4.0/). 